\title{
OPINION POLLING IN CENTRAL AND EASTERN EUROPE UNDER \\ COMMUNISM
}

\author{
Matt Henn
}

\section{DOI: $10.1177 / 002200949803300203$ \\ Journal of Contemporary History, 1998 Vol.33 (2): 229-240}

The online version of this article can be found at:

http://jch.sagepub.com/content/33/2/229.citation

Whilst political opinion polling occupies a well-entrenched position within contemporary capitalist political systems, the same cannot be said for the countries of Central and Eastern Europe. This paper focuses primarily on the development of political opinion polling in these countries in the period prior to the collapse of communist regimes there at the end of 1989. Polling was a feature of these communist-led societies, although it was limited in terms of its activities, the scope of issue coverage, and its ability to measure public opinion effectively. The major focus of the discussion concentrates on the methodological issues and problems confronting opinion pollsters in these societies during this time.

\section{The Development of Opinion Polling Under Communism}

Although it is generally recognized that public opinion polls were not carried out in the Soviet Union and other Central and East European countries until the 1950s ${ }^{1}$, documentary evidence does exist which suggests that polling activities can be traced as far back as 1945 in both Hungary ${ }^{2}$ and in Czechoslovakia. ${ }^{3}$ For instance, the Hungarian 
Institute of Public Opinion Research (HIPOR) was set up in August 1945, as a branch of the Hungarian Press Agency, '...organized after the manner of the American Institute of Public opinion'. ${ }^{4}$ It conducted research into how public opinion reacted to a variety of political events and issues, and how it perceived political parties, leaders, policies and programmes. At the general election in 1945, it accurately forecast the levels of support for the five main parties with an average error of less than $2 \%$ per party.

In the immediate aftermath of the Second-World War, the liberation from Nazi occupation in Czechoslovakia ushered in a series of conditions necessary for the establishment of opinion polling in any country. These conditions were:

-the emergence of an open and competitive party system;

-the freedom to express opinions without fear of retribution;

-relatively unobstructed information diffusion within society;

-and a necessity for political elites to establish lines of communication with the mass citizenry.

As a consequence of these developments, the Czechoslovak Institute of Public Opinion Research (Ceskoslovensky Ustav Pro Vyzkum Verejneho Mineni, hereafter $U V V M)$, was set up at the end of 1945 as an independent research organization. The formal operating policy of $U V V M$ was that it should gauge public opinion on political, social and economic issues, to provide the raw material through which policy-makers could identify the needs and aspirations of the citizenry, and legislate accordingly. Furthermore, all surveys were to be conducted in the public interest, rather than for any sectional or partisan advantage. As its founder members explained, one key objective of the polling institute was that there should '...be no alliance with any particular political party, and no propaganda for any particular ideology, 5 In this early period, the opinion 
pollsters in Czechoslovakia operated with a fair degree of autonomy from the state, and their (predominantly governmental) sponsors. There was little governmental intervention in, or censure of $U V V M$ 's polling activities, and the polling institute was relatively free to conduct research into any area of politics, economics, society or culture. Furthermore the data was publicly available in the monthly journal Verejne Mineni (Public Opinion). In its first year, $U V V M$ conducted polls which were designed to help the reconstruction of political structures and apparatus after the period of repression, and the suspension of democracy which had characterized German occupation between 1939 and 1945. The public was asked to consider the most effective methods for reorganizing the administrative mechanisms at local, district and provincial level and their reactions to plans for curbing the influence of the traditional state structures, and of broadening the powers of elected representatives in the newly established National Committees. Furthermore, the polls sought to identify which further reforms could be implemented to democratize the political system. The leaders of the Czechoslovak resistance movement had agreed upon a joint Government Programme at Kosice during the final phase of the country's liberation, which formalized the political structure of the new state, and guaranteed representation in government of all political parties. This programme for political reconstruction was accompanied by the Two Year Plan, a blue-print for economic rehabilitation. The polls monitored the public's awareness of, and reactions to these programmes, together with their perception of the government's performance, and the popularity of ministers and party leaders. ${ }^{6}$

$U V V M$ also conducted a pre-election poll for the May 1946 general election. During this period, there was 'limited' political pluralism - before the German invasion, there were approximately thirty political parties in Czechoslovakia, but after the war, there were only eight (four in Bohemia and Moravia-Silesia, and four in Slovakia). The 
union of five of these parties formed the National Front, a grand coalition government with no legitimate opposition. At the election, the Communist Party secured $40 \%$ of the votes and 114 of the 300 seats. With the support of the Social Democrats, they mustered a majority in Parliament, and were invited by President Benes to form a government. The performance of $U V V M$ in accurately forecasting the outcome of the election to within $1.1 \%$ of the final results was an indication to the public and to policy-makers alike, of the ability, effectiveness and validity of polls in measuring public. The success of $U V V M$ at the election led to a proliferation of political opinion polling by the institute.

In February 1948, the coalition government was replaced by a government composed of members of the Communist Party and its supporters from other parties. Elections were then proposed for May of that year, and Gottwald pronounced that the Party would secure the largest share of votes, and that this would signal majority support for their plans to revolutionize Czechoslovakian life. $U V V M$ organized three pre-election polls to test the levels of support for the parties, and to forecast the likely outcome of the election. However, after the questionnaires from the first wave of the survey were collected, they were confiscated by government officials. Nonetheless, they had already been processed by hand, and a visiting American journalist learned that the results suggested that the Communist Party would gain only about $30 \%$ of the votes cast at the forthcoming election, much less than the $40 \%$ achieved at the election in $1946 .^{7}$ Such a finding might have had a damaging effect on the Communist Party, calling into question their claims to represent the mass of the populace, and undermining their ambitions for constructing a new state and society based on the Stalinist-model which had developed in the Soviet Union. The view held by the new communist-led government of polling was one of suspicion: the prospect of an independent opinion polling institution, publishing findings which ran contrary to the propaganda of the Party, and which denied 
the alleged consensus of public support for the values and aims of Marxism-Leninism, was perceived by the party leadership as intolerable. ${ }^{8}$ Furthermore, the polling methodologies had been imported by Adamec and Viden from the USA, when they visited Albert Cantrill and George Gallup shortly after the war. The methodologies they used when they returned were a direct reflection of those employed by the pollsters in capitalist countries. Samples were generated using a quota method (based on gender, age, social class, community size and geographical distribution); personal interviews were conducted with structured questionnaires. ${ }^{9}$ In a period of mutual suspicion between the Western capitalist bloc, and the new communist-led countries, it was perhaps not surprising that the authorities were critical of opinion polling activities.

As a consequence, the period after the ascendance to political power of the Communist Party in February 1948, was one of repression for opinion polling in Czechoslovakia. UVVM was permitted to continue its activities for a further two years but only after it had been reorganized, and only in the context of enquiring into nonpolitical issues. The chief editor of Verejne Mineni was forced to leave the building immediately the Communist Party had assumed control of the government, and the journal was closed down. The institute's entire personnel, none of them members of the Communist Party, were sacked; one founder-member, Cenek Adamec, was imprisoned, and later forced to work in a factory. The combination of these events led ultimately to the gradual disappearance of Czechoslovakian opinion polling. ${ }^{10}$

In fact, public opinion research was also largely perceived as an irrelevant activity within the communist-led countries. In the Soviet Union for instance, under Stalin's leadership, “...the instruments by which public opinion was discovered included the secret police, the party apparatus...letters to the mass media, and 'self-criticism"". ${ }^{11}$ Worcester observes that, between '...1930 and the mid-1950s, the Soviet leadership 
tended to assume that party cadres, aided by KGB sources and informants, knew what needed to be known about the citizenry's needs, attitudes and preferences'. ${ }^{12}$ Furthermore, independent opinion polls which were geared towards reporting the publics' rating of the performance of the Party, and of the Party leaderships, and which sought to measure satisfaction levels with policy proposals and outcomes, were viewed by the party hierarchies as unnecessary. Stanislaw Kwiatkowski, former Central Committee member of the Polish Communist Party, and chief political (and polling) advisor to General Jaruzelski claims that:

'The picture of a differentiated society that emerged from the public opinion research did not fit the thesis on the moral and political unity of the nation obligatory at that time'. ${ }^{13}$

Communist governments throughout Central and Eastern Europe took a rather dim view of Social Science generally, and of social research methods and opinion polling. As a leading Polish opinion pollster during the communist reign in Poland during the 1980s, Piotr Kwiatkowski notes:

"During the Stalinist period, every attempt to express independent opinion on social or political issues was brutally suppressed. The notion of public opinion was officially condemned and sociology was banned from the universities of all communist countries as a Western 'pseudo-science"”. ${ }^{14}$

However, a large number of Central and East European countries had strong, established traditions in sociology that pre-dated the communist era. In Poland, Bulgaria, Yugoslavia, Russia, Czechoslovakia and Romania, sociology emerged in the latter half of the 1800 s as a social protest, rather than a purely academic discipline - indeed the 
absence of any official Hungarian sociology at this time has been ascribed to its association by governments with political radicalism and with socialist-inspired antiestablishment protests. Many early prominent sociologists in the region then were progressive, often socialist activists, who '...combined their sociological studies with an active engagement in various struggles for social justice, democratic freedom and national independence'. ${ }^{15}$ After the victory of the October revolution in 1917, sociology in the USSR become concerned with the study of the emerging socialist society and consequently, it was officially perceived as a method for understanding and contributing to the human condition; this was considered as serving a more useful purpose than the objectives of those who held a more traditional, humanistic view of sociology as the accumulation of knowledge for knowledge's sake. In this latter context, objective, empirical sociological research was seen as alienated from the problems of human society by communist leaderships, and was irrelevant in the struggle for constructing an international socialist community. ${ }^{16}$

With the political ascendancy of the Stalinist bureaucracies, sociological research, with the exception of the official Marxist-Leninist approach, was virtually nonexistent up until the end of the 1950s. Empirical-quantitative studies of society and politics were criticized because they were identified with a broadly Western, chiefly American orientation to the study of society. Attila notes that, as a consequence:

'Political science did not simply disappear after a small period of emergence and early successes in democratization (1944-48) but it was banned as a pseudo-science of the bourgeoisie - an autocratic rule does not need the science of Democracy'. ${ }^{17}$

The suppression of sociology then, in the period up until the end of the 1950s in Central and East European communist political systems was a function of the political 
leaderships' view of it as 'bourgeois politology', and 'reactionary political science', and as a threat to communist hegemony. ${ }^{18}$

In the light of these discussions, it is not surprising that the early communist regimes demonstrated little enthusiasm for opinion polling. However, there is some evidence of polling taking place in communist-led societies, although these polling institutes were usually set up, financed, controlled, and accountable to the ruling Party. When attempts were made to reassess the nature of society and encourage political debate, sociology and ultimately opinion polls were endorsed. Shlapentokh characterizes this relationship between the State, Party and social science-based research as one in which political-environmental factors were paramount. Thus, in periods of Stalinist ascendency, sociology and hence social and political research were largely repressed, and in reform periods, such as the 'golden age' of Soviet sociology (1965-72) and later, at the end of the 1980s, controls and censorship were relaxed, and in many communist political systems, institutions were set up to explore sensitive, often 'political' issues. Hence, when Nikita Khrushchev assumed the leadership of the Soviet Union, sociology was rehabilitated; in 1960, Boris Grushin, one of the founders of Soviet sociology established the Institute of Public Opinion, based at the newspaper Komsomol'skaia pravda, and in 1961 the Party leadership endorsed the founding of a section for sociological research at the USSR Academy of Sciences Institute of Philosophy. Generally, the areas for research were largely restricted to social and economic issues concerned with work, family life and living standards. However, between 1965 and 1972, the research began to investigate political and current affairs issues - an unprecedented development in the direction of Soviet sociology. In 1968, the Institute for Concrete Social research was endorsed by the Politburo of the CPSU, and was involved in conducting a series of projects within the 'political' realm of Soviet life. However, the political repercussions 
of the Prague Spring had a significant impact on the activities of this and other social and political research centres. It precipitated a crisis of confidence amongst the Soviet leadership, which then embarked upon a generalized campaign of political repression aimed at 'intellectuals', and their most visible manifestation, empirical sociologists. In 1971, the CPSU sanctioned a large scale purge of the Institute for Concrete Social Research, and its polling branch, the Centre for the Study of Public Opinion was closed. ${ }^{19}$ However, during the 1980 s, the communist leaderships in the Soviet Union gradually warmed to the idea of conducting and publishing opinion polls, although early studies were limited in scope of issues covered: in 1983, the Soviet leader Yuri Andropov announced that a national institute of public opinion would be formed to cover the entire USSR. ${ }^{20}$ Slider observes that the rationale was based upon the experiences of a public opinion centre created by the Georgian Communist Party. There, the reform-minded Shevardnadze frequently cited polls as an aid to policy-making and agenda-setting. ${ }^{21}$ As a result of Mikhail Gorbachev's 'Glasnost' and 'Perestroika' programmes, such centres were actually established the following year. ${ }^{22}$ The development of these polling centres is explained by Valery Korobeinikov in terms of the role that they could take for the government in initiating and extending the processes of political democratization. In the first instance, he observes that the spirit of public opinion research was written into the Soviet constitution of 1977 , which stated that the extension of socialist democracy is closely connected with '...greater openness and publicity, and constant responsiveness to public opinion'.23 Secondly in a more concrete sense, polls assisted politicians by identifying public attitudes to reform; they provided feedback from citizens in relation to government plans, and therefore assisted policy-formulation and implementation. On political reform, public opinion polls were conducted to help clarify voters' attitudes to innovations in the electoral system (particularly the secret ballot) and the nomination of 
party candidates. ${ }^{24}$ Finally, Korobeinikov argues that polls were utilized by the ruling Communist Party '...to improve the work of the various party committees'. Thus, two republic-wide polls were conducted in Georgia in late 1986 where '...respondents were given the opportunity to evaluate the activities of all governing bodies in the republic...[and to] indicate problems caused by Cadre policies simply seen as incorrect' ${ }^{25}$ Polling institutes were established in many other Central and East European countries during the communist era, including for instance Hungary, Poland, Czechoslovakia, Yugoslavia, Romania, and Bulgaria. ${ }^{26}$

Many of these polls were limited in terms of their ability to provide accurate representations of public opinion. White et al for instance describe the nation-wide network of polling centres established by Zaslavskaya in 1988 across the Soviet Union (VtsIOM) and comment upon their general unreliability, and large margins of error. Sample sizes were not sufficient to account for the population diversity, and extreme regional variation undermined the efficacy of polls in providing typical national pictures of public opinion. Furthermore, certain groups were over-represented - including ethnic Russians, urban respondents, and those in the larger settlements - which inevitably reinforced the sample bias. Data was usually aggregated, so that differences in response across key variables such as gender, age, nationality and social group could not be identified, and temporal comparisons were unachievable because of the lack of questionwording consistency across polls. ${ }^{27}$ This raises a key issue when describing the development of polling in communist societies: methodological limitations of polling organizations in seeking to measure public opinion. This is discussed below in relation to Polish polling experiences, which raises general issues which can be applied to other communist contexts. 


\section{Methods and Issues In Polling Communist Political Systems}

Political opinion polls conducted in the countries of Central and Eastern Europe had their methodological origins in the USA and Western Europe. ${ }^{28}$ Prior to the Second World War, most sociological research was qualitative-based ${ }^{29}$, but the new techniques imported from the West employed the survey-sample method. The following discussion focuses on various issues which emerged as researchers under the direction of Stephan Nowak and Zygmunt Gostkowski attempted to apply American political science techniques to Poland. It suggests that there are certain key methodological problems in polling public opinion which are common in all communist political systems ${ }^{30}$, and which are linked to the social and political context of questionnaire interviewing. These include: the levels of non-response in such political surveys; the problems associated with 'don't know' responses; and the influence of third parties in the interview process, together with the context of the interview.

\section{The Interview Situation and Non-response}

It is possible to differentiate two official models of the interview situation and the role of the respondent, which pertain in capitalist and in communist societies. ${ }^{31}$ The first model assumes that in countries like America and Britain, the respondent is strongly motivated towards providing 'true' answers, and this derives from a belief in the usefulness of social studies and of the expression of one's own opinions. This model can be challenged in the light of recent empirical evidence, especially in relation to the British general election polls in $1992^{32}$. A second model, developed by various sociologists in communist-led countries, assumes that the respondent has a positive attitude towards the interview, and is prepared to express his, or her 'real' opinions, since social research contributes to the solution of social problems. It is claimed that the interview unites both 
the researcher and the respondent as partners in their efforts to improve social life. Both approaches focus on the attitudes of a 'model citizen', and a resultant uncritical perception of the purposes of social research.

However, the findings of researchers at The Polish Academy of Sciences Institute of Philosophy and Sociology (hereafter IFiS) suggest that neither model is applicable to Poland under conditions of communist rule. They maintain that the public closely associated '...sociology, and social and political research with the state, its institutions, and the system of political power'. ${ }^{33}$ Social surveys and political opinion polls were perceived to be linked to governments' propaganda strategies - part of a process whereby public opinion data was collected, and then manipulated and reported in such a way as to disseminate information publicly purporting to demonstrate universal support for the government, and the principles and programme of Marxism-Leninism. ${ }^{34}$ There was little sense that polls could help either to facilitate beneficial changes within society and for individuals generally, or that such data was taken into account in formulating and implementing policies. Such polls were therefore observed with a large degree of ambivalence and scepticism by the public. ${ }^{35}$

A common view identified amongst the public was that polling research was state-sponsored in order to monitor citizens' loyalty to the government, and control their consciousness. As such, many people were reported by IFiS to be afraid of revealing any opinions which might in some way incriminate them, or lead to retribution from the state. The granting of an interview often requires therefore a suppression of fear and apprehension. On the basis of these findings, it is surprising then that people took part in opinion polls at all in communist political systems. Indeed, Lutynska reports that at the end of the 1970s, the refusal rate in surveys conducted by $O B O P$ in Poland was only about $12 \% .^{36}$ This apparent contradiction is explained in terms of two major factors. 
Firstly, respondents' behaviour is governed by a traditional, and deeply internalized cultural norm requiring them to be hospitable to people, including strangers. This accounts both for people inviting interviewers into their homes, and for volunteering to take part in political surveys. Secondly, the interviewer is usually treated as a representative of a state agency, which forms part of the dominant power system. It is thus possible that ' ...fear of running into troubles or of being called to account for a refusal of interview dominates over the feeling of apprehension resulting from participation in the interview' ${ }^{37}$

The publics' reaction to opinion polling was however dependent on the political climate at the time of interview. Przybylowska and Kistelski observe that during the reform period under Wladyslaw Gomulka in October 1956:

'...a hope for changes in the execution of political power and prospects for gradual democratization of social life and for free expression contributed to, and facilitated the introduction of opinion polls ${ }^{38}$

However, the introduction of Martial Law in December 1981 effectively stifled spontaneous and open expression of social and political opinions. Indeed, by 1982 '...the question was even raised whether it made any sense to conduct questionnaire surveys in Poland... [because of] concern about refusal to take part in questionnaire surveys' ${ }^{39}$ Refusal rates were often recorded between $40 \%$ and $50 \%$ during this period, and these varied according to socio-economic and demographic status, and between regions and cities. Ultimately, sample-surveys were often biased under Martial Law conditions. A number of factors have been identified which help to explain both these low levels of response, and of response variation. Lutynska claims that sponsorship of the research tended to make a significant impact here. The highest rate of refusals occurred in polls 
conducted by state-controlled organizations (OBP 28-50\%, CBOS 23-44\%, OBOP 1628), whilst in academic surveys non-response ranged between only $3 \%$ and $4 \%$. Furthermore, the name of the research centre may also influence respondents' willingness to take part in such research. A common problem for the Centre for Press Research $(O B P)$ was that they were associated with newspapers which had a low credibility rating amongst large sections of the public: '...people do not want to speak with representatives of the press, since they fear that their answers will be twisted, passed on to non-academic centres, or may be used for propaganda purposes contrary with their own beliefs' ${ }^{40}$ The subject of the research also played a significant role in reducing the levels of public participation in polls - especially politically sensitive topics. When combined with the effects of other factors such as sponsor of the poll, political context in which it was conducted, and generalized public concern for lack of anonymity in such surveys, this was seen as a major impediment to the achievement of representative polls. Finally, interviews were often associated with government officials, the police and security services, and activists of the ruling Communist Party (the PUWP); in the context of Martial Law, the fear of retribution from the state for criticizing the authorities and the principles of Marxism-Leninism in polls was greater than in other periods of communist rule. $^{41}$

\section{The Incidence of 'Don't Know' Responses}

During the Martial Law period, respondents in opinion polls were likely to exercise some discretion in answering questions on politically sensitive topics by registering 'don't know' responses where they felt that the expression of their views might lead to some punitive action by the authorities. The use of such replies was therefore a means through which people could disguise their non-response in polls. 
Lutynska's research has found that during the period 1980-1985, the number of such replies trebled for questions which were 'easy but sensitive'; she claims that question sensitivity was a more important factor than question complexity, or lack of knowledge about the issue polled. ${ }^{42}$ Kwiatkowski reports that the incidence of such responses were variable, particularly marked in terms of educational level, and influenced by the 'sponsorship' factor: respondents were more likely to answer 'don't know' to politicallysensitive questions polled by the state-controlled institute $C B O S$, than by the academic IFiS. ${ }^{43}$ This suggests that the reliability of many political opinion polls - particularly those conducted by state-owned and controlled agencies - and the validity of the data collected was extremely limited in communist political systems.

\section{The Presence of Third Persons in Interviews}

Research at IFiS has also revealed that the presence or absence in the course of an opinion poll interview of third parties will have a major impact on the reliability of the data collected. This will be further complicated by the context in which the interview is conducted. ${ }^{44}$ In the first instance, Lutynska reports that in a series of surveyexperiments between 1966 and 1968, the percentage of interviews in which third persons took part ranged between $27.4 \%$ and $63.7 \%$, depending on the research topic; the average rate was $46.1 \%$. This factor was accountable for a difference in respondents' expressed answers by up to a margin of $20.1 \%$. Furthermore, such situations tended to vary according to various social and spatial milieus, which suggests that the results obtained in any such research were likely to be skewed. Third persons were also likely to participate as 'active respondents', rather than passive listeners in the polls: 
'...the respondents may be reminded of certain facts or prompted, the strangers may present their views and opinions on the subject in question, they may make remarks referring to the questions, the interviews or the respondent, they may even begin discussions and quarrels in connection with some of the problems taken up in the interview'. ${ }^{45}$

This poses the question of how to interpret the findings: whose opinions are the subject of research - the individual, or the group?

Jan Lutynska observes that in later studies conducted by IFiS in the 1970s, researchers found that different answers were given by respondents according to the location of interviews. Lutynska concludes that in general, a home atmosphere was more conducive to the expression of private opinions (especially on political issues) whereas in a work environment, participants were likely to concur with what they perceived were the 'official' positions on these topics.

Summary

This paper has demonstrated that the main methodological issues confronting the opinion pollsters in communist political systems were directly related to the political atmosphere which pertained there. Essentially, respondents' refusals to participate in polls were manifest in terms both of avoiding taking part in polling interviews, and by answering 'Don't Know' at strategic points within the interview. Generally, respondents attached a low value to the efficacy of political opinion polls, and the motivation to take part, especially in periods where traditionalist-Marxist-Leninists were dominant within the key political institutions of the state, was low. This lack of public co-operation in polls was summarized by Lutynska: 
“...they are afraid, do not believe in the anonymity of the survey, believe that this is a 'waste of time', 'makes no sense', will change nothing', 'is of use of nobody'...[or] would be doctored-up and used for propaganda purposes". ${ }^{46}$

Furthermore, the absence of political tolerance, and rights of free expression inclined many respondents to avoid making public utterances on the political set-up, government leadership, and current affairs, for fear of retribution by the state. Instead, where citizens felt compelled to take part in political surveys, they were likely to disguise their real opinions if they feel that these did not correspond with the official issue-positions as reported in the mass media, or else stated that they did not have an opinion. This was particularly likely in polling institutions associated with the state. Response rates were also variable. Consequently those who did participate in polls were unlikely to be representative of the full population, and the polls themselves to be unreliable indicators of the state of public opinion.

\section{Notes}

${ }^{1}$ P. Kwiatkowski, 'Opinion Research and The Fall of Communism', International Journal of Public Opinion Research 4, 4 (1992), 359

${ }^{2}$ Hungarian News Agency, Results of Hungarian Public Opinion Research, (Budapest 1947)

${ }^{3}$ C. Adamec and I. Viden, 'Polls Come to Czechoslovakia', Public Opinion Quarterly, Winter $(1947 / 48)$

${ }^{4}$ Hungarian News Agency, op. cit.

${ }^{5}$ C. Adamec and I. Viden, op. cit., 550

${ }^{6}$ C. Adamec, B. Pospisil and M. Tesar, What's Your Opinion: A Year's Survey of Public Opinion in Czechoslovakia (Prague 1947) 
${ }^{7}$ D. Adams-Schmidt, Anatomy of a Satellite (Boston 1952)

${ }^{8}$ C. Adamec, Fear and Hope in 1968, Unpublished Paper (Prague 1991), 1-2

${ }^{9}$ C. Adamec and I. Viden, op. cit.

${ }^{10}$ C. Adamec, op. cit.

${ }^{11}$ Z.Y. Gitelman, 'Public Opinion In Communist Political Systems', in Connor, W.D. and Gitelman, Z.Y. Public Opinion in European Socialist Systems (New York 1977), 2

${ }^{12}$ R.M. Worcester, 'The Internationalization of Public Opinion Research', Public Opinion Quarterly, 51, (1987), S82

${ }^{13}$ S. Kwiatkowski, The Study of Public Opinion in Poland, Unpublished Paper, (Warsaw 1989), 4

${ }^{14}$ P. Kwiatkowski, op. cit., 358

${ }^{15}$ J.J. Wiatr, The State of Sociology in Eastern Europe Today (London 1971), .4

${ }^{16}$ Ibid.

${ }^{17}$ A.G.H. Attila, 'The Emergence of the Science of Democracy in Hungary and Its Impact on the Democratic Transition', paper delivered at the conference of the International Committee for The Study of The development of Political Science (Barcelona 1990), 3

${ }^{18}$ E.A. Ivanian, 'The Effect of Perestroika on the Development of political Science in The USSR', paper delivered at the conference of the International Committee for The Study of The development of Political Science (Barcelona 1990), 2

${ }^{19}$ For a complete overview of the influence of political factors in Soviet society, see V. Shlapentokh, The Politics of Sociology In The Soviet Union, (Boulder and London 1987), chapters 1 to 4 , and chapter 13

${ }^{20}$ S. White, R. Gill, and D. Slider, The Politics of Transition: Shaping a Post-Communist Future, (Cambridge 1993), 180-183

${ }^{21}$ D. Slider, 'Party-Sponsored Public opinion research in The Soviet Union', Journal of Politics, 47, 1 (1985), 209-227

${ }^{22}$ P. Kwiatkowski, op. cit., 359-360 
${ }^{23}$ V. Korobeinikov, 'Opinion Polls in The soviet Union: Perestroika and The Public', European Research (1988), 160

${ }^{24}$ Ibid, $161-2$

${ }^{25}$ Ibid, 161

${ }^{26}$ See for instance J.A. Piekalkiewicz, Public Opinion in Czechoslovakia 1968-69 (New York 1972); W.D. Connor and Z.Y. Gitelman, op. cit.; W.A. Welsh, (ed.) Survey Research and Public Attitudes in Eastern Europe and The Soviet Union (Oxford 1981); G. Klein and J. Krejci, 'Czechoslovakia', in W.A. Welsh op. cit.; R.M. Worcester, op. cit.; S. Kwiatkowski, op. cit.; P. Kwiatkowski, op. cit.

${ }^{27}$ S. White, R. Gill and D. Slider, op. cit., 182-183

${ }^{28}$ See V. Shlapentokh, op. cit., 21-22

${ }^{29}$ K. Lutynska, IFiS, Personal Interview (Lodz 1991)

${ }^{30}$ Of course, considerable differences in terms of the development of sociology and sociological research did exist between these countries, especially between the Soviet Union and other Central and East European communist states. For instance, Jones claims that whilst in countries like Poland, Yugoslavia and Hungary sociologists were often involved in subversive activities and organizations, the same could not be said for those in the Soviet Union (A. Jones, 'Soviet Sociology, Past and Present', in Contemporary Sociology [1989] 319-19). Other differences in polling developments, practices and conditions across these communist political systems occurred in terms of: the degree of state interference and decentralization of planning, coordination and funding of the research; the extent of formal empirical sociology training amongst the practitioners; quality of methodological approaches and techniques, particularly in terms of sampling procedures and data analysis; the actual frequency with which such polls were conducted; and the role of polling data in policy development and review (see for instance W.A. Welsh, 'An Overview of the Status of Survey Research in Eastern Europe and The Soviet Union', in Welsh, W.A. op. cit. 5-12, and Z.V. Gitelman, op. cit., 9-11). However, if compared to their counterparts in western liberal- 
capitalist societies, it is possible to see significant similarities in the experiences of pollsters in Central and East Europe to make such generalizations meaningful for analytical purposes.

${ }^{31}$ I. Przybylowska and K. Kistelski, 'The Social Context of Questionnaire Interviews', The Polish Sociological Bulletin, 3-4 (1986)

${ }^{32}$ See for instance I. Crewe 'A Nation of Liars? Opinion Polls and The 1992 Election', Parliamentary Affairs 45, 4 (1993) 475-95; R. Jowell et al 'The 1992 British General Election: The Failure of The Polls', Public Opinion Quarterly, 57 (1993) 238-63; N. Sparrow 'Improving Polling Techniques Following The 1992 General Election', Journal of Market Research Society, 35,1 (1993) 79-89.

${ }^{33}$ Ibid, 22

${ }^{34}$ P. Kwiatkowski, op. cit., p.363

${ }^{35}$ I. Przybylowska and K. Kistelski, op. cit., p.24

${ }^{36}$ K. Lutynska, 'Questionnaire Studies in Poland in The 1980s: Analysis of refusals to Give An Interview', The Polish Sociological Bulletin, 3 (1987), 47

${ }^{37}$ I. Przybylowska and K. Kistelski, op. cit., 25.

${ }^{38}$ Ibid, 26

${ }^{39}$ K. Lutynska, (1987), op. cit., 44

${ }^{40}$ Ibid, 48

${ }^{41}$ Ibid, 48-50

${ }^{42}$ These findings are reported by Krystyna Lutynska in 'Replies of the Type "It is Hard to say" in the 80 s and their Determinants' from an un-dated collection of essays on survey methodology by Z. Gostkowski presented to the author.

${ }^{43}$ P. Kwiatkowski, op. cit., 367

${ }^{44}$ J. Lutynska, Methodological Studies in Lodz Sociological Centre, Unpublished paper presented to the author on a research visit to Lodz in May 1991 (Year Unknown); K. Lutynska, "Third Persons in Sociological Interviews and Their Influence on The Respondents' Replies", The Sociological Bulletin, 3 (1969)

${ }^{45}$ K. Lutynska, ibid, 140 
${ }^{46}$ K. Lutynska, 1987, op. cit., 50-51

\section{Matt Henn}

is a lecturer in Research Methods at the

Department of Economics and Politics,

The Nottingham Trent University. He has a doctorate in Politics which compares the development of opinion polls in late-capitalist and post-communist societies, and has published in the area. 